Distribution and Supervision of Oral Contraceptives

M. V. Smith, M.F.C.M., and others......161

Mid-trimester Termination

S. M. M. Karim, PH.D., and S. S. Ratnam,

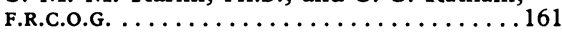

Screening for Sickle-cell Disease

D. I. K. Evans, M.R.C.P.ED.; F. F. Casale,

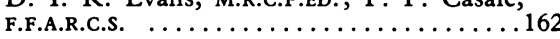

Familial Trends in Low Birth Weight

Margaret K. Ounsted, D.M...........163

Experts and Child Abuse

J. R. Mathers, F.R.C.PSYCH. . . . . . . . 163

Drug-induced Red Cell Aplasia

D. MacCulloch, M.B., and others........ 163

Nephrotic Syndrome in Chronic

Lymphocytic Leukaemia
J. S. Cameron, F.R.C.P., and C. S. Ogg, M.D. . . 164
Mouth Ulceration and Slow-release

Potassium Tablets

Bost-herpetic Pruritus

K. Liddell, M.R.C.P...

Ka Condition Humaine

J. R. M. Millar, M.R.C.G.P...

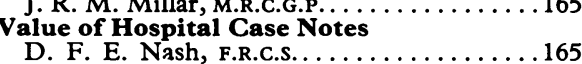

Lead and Intelligence

D. Bryce-Smith, D.SC., F.R.I.C., and others. . 165 Semen Cryobanking

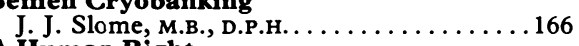

A Human Right

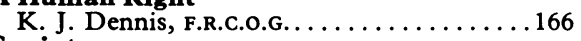

Squint

B. S. Jay, F.R.C.S

Tuberculous Lymphoedema

F. L. Ashworth, F.F.A.R.C.

Price of Prostatectomy

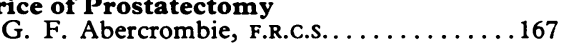

"Lost Threads" with Intrauterine Devices

J. Guillebaud, F.R.C.S.ED., and J. M. Kasonde,

M.R.c.o.G. . ...................167

Fatal Puerperal Septicaemia

G. Gennser, M.D., and others . . . . . . . 167

Cervical Plasma Cell Population in

Infertile Patients

Rosalind A. Hinton, M.B. . . . . . . . 168

Gaps in Medical Research

E. M. Backett, F.R.C.P............. 168

"Continuing Clinical Responsibility"

P. H. Beales, F.R.C.S.ED.; W. L. Munro,

M.B., D.M.R.D................. 168

Financing the N.H.S.

D. D. Cracknell, M.B., B.s.; G. J. Wilcox,

M.B. .....................169

A Bad Week

A. A. Stephen, M.B. . . . . . . . . . . . . . . . . 169

Increase in N.I. Payment for Self-employed

J. Goldie, M.R.C.G.P.; J. P. Telling, M.B.....169

\section{Distribution and Supervision of Oral Contraceptives}

SIR,-When oral contraceptives were first in:roduced in the United Kingdom in 1960 it was reasonable to restrict the use of these unknown and relatively powerful drugs solely to prescription by doctors. However with $2 \frac{1}{4} \mathrm{~m}$. users, with an increasing understanding of long- and short-term side effects, and with some significant reductions in dose the need now arises to review the available methods of distribution and supervision.

Oral contraceptives have proved effective in preventing pregnancy and are relatively simple to use, and the health benefits of their use almost certainly outweigh the risks of use in nearly all cases. As with all effective therapies there is a continual obligation both to use the available medical skills as effectively as possible and to review the accessibility of the therapy to those in need. Any increase in the use of oral contraceptives, by preventing unplanned pregnancies and induced abontions, will make a contribution towards further reducing maternal mortality as well as increasing the quality of life for parents and their children.

Any method of distriburing oral contraceptives and supervising continued use must meet a number of needs: it must protect users against any predictable risks, it must allow for continued monitoring of side effects, especially long-term effects, so that the remaining unknowns can be answered as soon as possible, it must use the skills of the medical team-doctor, midwife, nurse, health visitor, social worker, or lay counsellor-as effectively as possible, and it must offer the maximum convenience and easiest possible access for women who wish to use oral contraceptives.

Accessibility of initial and resupply packs of oral contraceptives is one variable determining acceptance and continuation of use, and the limitation of oral contraceptives to a doctor's prescription can increase the geographical and social distance between the user and provider as well as burdening an overstretched medical service. Observation shows that prescription means different things to different doctors, varying from frequent thorough physical examination to the briefest possible interview. Variations in clinical practice may contribute to the fact that some women have a confused image of oral contraceptives. As a consequence of the present system of distribution unplanned pregnancies and induced abortion, which might otherwise be avoided by the voluntary limitation of fertility, continue.

We conclude that it would be a responsible and constructive step forward in medical practice to widen the range of those empowered to dispense oral contraceptives to include state registered nurses, midwives, and health visitors who have had some additional training in contraceptive practice. As in other circumstances where non-doctor health personnel dispense pharmacologically

\section{Mid-trimester Termination}

SIR,-Your leading article on the use of prostaglandins for mid-trimester abortion (17 August, p. 428) is very timely since these compounds are now commercially available in several countries (including the U.K.) and are likely to be widely used. The recent reports of cervical rupture are disturbing and your article rightly emphasizes the need for carrying out second-trimester terminations in a fully equipped unit. It is estimated that $\mathrm{PGF}_{2 \alpha}$ given by the intrauterine route has been used in over 5,000 patients for the termination of late pregnancy and so far 13 cases of cervical rupture have been reported. Details of these cases are given in the table.

The reported cases of cervical rupture have several features in common: (1) Most ruptures have occurred in young primigravidae. (2) All were given $\mathrm{PGF}_{2 \alpha}$ intra- active compounds (or are involved in important procedures, such as delivery of a baby) the doctor would continue to supervise the service and would deal with oomplicated cases referred to him. We also believe in the need for the user of any method of contraception to have the fullest possible confidence in that method and suggest that any woman who wishes to see a doctor when starting oral contraceptives or during their use should continue to do so. -We are, eitc.

MICHAEL SMITH
E. M. BACKETT
DUGALD BAIRD
R. W. BEARD
PETER BISHOP
JANET BOTTOMLEY
STANLEY CLAYTON
IAN D. COORE
G. C. CURTIS
DENYS V. I. FAIRWEATHER
ELIZABETH H. GREGSON
PETER J. HUNTINGFORD

UNA L. KROLL JOHN A. LORAINE ELEANOR MEARS J. NEWTON MARY PEBERDY MALCOLM POT'S K. M. REID ALWYN SMITH G. I. M. SWYER A. C. TURNBULL
MARGARET C. WATKINSON

London S.W.14

amniotically (with one exception who received a combination of $\mathrm{PGE}_{2}$ and $\mathrm{PGF}_{2 \alpha}$ ). (3) All were in the second trimester of pregnancy (gestation 15-22 weeks). (4) In most cases either high doses of $\mathrm{PGF}_{2} \alpha$ were given or additional oxytocics used.

It is just over three years since prostaglandins were first used intra-amniotically for the termination of second-trimester pregnancy. ${ }^{78}$ During these years investigators have used different dose schedules in order $(a)$ to reduce the injection-abortion interval and $(b)$ to make the termination of second-trimester pregnancy with intraamniotic prostaglandins a single-injection procedure. To achieve this lange doses of prostaglandins have been used and often supplemented by other oxytocics (intraamniotic urea or intravenous oxytocin). Cervical rupture could then be the result of 


\begin{tabular}{|c|c|c|c|c|c|c|}
\hline $\begin{array}{l}\text { Case } \\
\text { No. }\end{array}$ & $\underset{(\mathrm{yr})}{\text { Age }}$ & $\begin{array}{c}\text { Gestation } \\
\text { (weeks) }\end{array}$ & Parity & Prostaglandins, Dose and Route & Comments & References \\
\hline $\begin{array}{l}1 \\
2 \\
3\end{array}$ & $\begin{array}{c}\text { N.S. } \\
16 \\
19\end{array}$ & $\begin{array}{l}18 \\
21 \\
20\end{array}$ & $\begin{array}{l}0 \\
0 \\
0\end{array}$ & $\begin{array}{l}\mathrm{F}_{2} \alpha 30 \mathrm{mg} \text { i.a. } \\
\mathrm{F}_{2} \alpha 30 \mathrm{mg}+25 \mathrm{mg} .8 \mathrm{hr} \text { later i.a. } \\
\mathrm{F}_{2} \alpha 30 \mathrm{mg}+25 \mathrm{mg} \text { at } 8 \mathrm{hr}+ \\
25 \mathrm{mg} \text { at } 24 \mathrm{hr}+25 \mathrm{mg} \text { at } \\
34 \mathrm{hr} \text { i.a. }\end{array}$ & $\begin{array}{l}\text { Cervical repair } \\
\text { Cervical repair } \\
\text { Twin pregnancy, } \\
\text { last dose given } 7 \\
\text { hr after artificial } \\
\text { rupture of } \\
\text { membranes }\end{array}$ & $\begin{array}{r}1 \\
2 \\
2 \\
-\end{array}$ \\
\hline $\begin{array}{r}4 \\
5 \\
6 \\
7 \\
8 \\
9 \\
10 \\
11 \\
12 \\
13\end{array}$ & $\begin{array}{l}15 \\
17 \\
17 \\
18 \\
19 \\
\text { N.S. } \\
\text { N.S. } \\
\text { N.S. } \\
\text { N.S. } \\
17\end{array}$ & $\begin{array}{c}15 \\
15 \\
17 \\
16 \\
15 \\
\text { N.S. } \\
\text { N.S. } \\
22 \\
22 \\
20\end{array}$ & $\begin{array}{c}0 \\
0 \\
0 \\
0 \\
0 \\
\text { N.S. } \\
\text { N.S. } \\
\text { N.S. } \\
\text { N.S. } \\
0\end{array}$ & 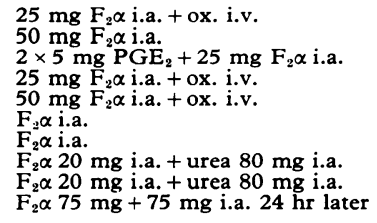 & $\begin{array}{l}\text { No cervical repair } \\
\text { Cervical repair } \\
\text { Cervical repair } \\
\text { Cervical repair } \\
\text { No cervical repair } \\
\text { _- } \\
\text { Cervical repair } \\
\text { Cervical repair } \\
\text { Cervical repair }\end{array}$ & $\begin{array}{l}3 \\
3 \\
3 \\
3 \\
3 \\
4 \\
4 \\
5 \\
5 \\
6\end{array}$ \\
\hline
\end{tabular}

N.S. $=$ not stated; ox. = oxytocin; i.v. = intravenous; i.a. = intra-amniotic

overstimulation of the uterus before the cervix has undergone softening and is ready to dilate.

To our knowledge so far, rupture of the cervix with intra-amniotic PGE. has not been reported. There are two possible reasons for this: (1) PGE, has not been used as widely as $\mathrm{PGF}_{2 \alpha}$ and (2) unlike $P G F_{\llcorner\alpha}, P_{2} E_{2}$ has a relaxant effect on the non-pregnant cervix in vitro ${ }^{9}$ and this effect may also extend to the pregnant cervix. We have used PGE. (intra-amniotically) in doses of $5 \mathrm{mg}$ (repeated 10-12-hourly if necessary) in over 500 second-trimester patients (30\% nulliparous) without a single incident of cervical rupture.

Though some synthetic analogues of prostaglandins are being clinically evaluated to overcome some of the disadvantages associated with the natural compounds, the potential danger of any oxytocic to the uterus as a result of overstimulation must always be borne in mind..$^{11}$ Need for improvements in techniques for the late termination of pregnancy still exists. Studies are directed towards gradual dilatation of the cervix with laminaria tents or with some synthetic prostaglandin analogues. Insertion of laminaria tents into the cervix at varying intervals prior to intra-amniotic prostaglandin instillation seems to reduce the injection-abortion interval, presumably by decreasing cervical resistance. ${ }^{1213}$ Prostaglandin analogues given as a single extraamniotic dose 12 or more hours prior to vaginal termination of first-trimester pregnancy has been shown to be effective in gradually dilating the cervix without overstimulation of the uterus. ${ }^{14} 15$ In a recent study we have used 15 (S) 15 me PGE in a single extra-amniotic dose of $25 \mu \mathrm{g} 14$ hours prior to vaginal termination. Out of a total of 88 women (all nulliparous, gestation 9-13 weeks) anly three required meahanical dilatation of the cervix and none required analgesia for uterine cramps.

We feel that prostaglandins offer an attractive alternative to hysterotomy or hypertonic saline for the termination of secondtrimester pregnancy provided overstimulation of the uterus with very large doses is avoided.-We are, etc.,

SUltan M. M. Karim S. S. RATNAM

University of Singapore,

Department of Obstetrics and Gynaecology,

Kandang Kerbau Hospital,

Singapore 1 Shearman, R. P., Smith, I.. and Korda, A.,
Fournal of Reproductive Medicine, 1972, 9, 448.
2 Wentz, A. C., Thompson, B. H., and King, Wentz, A. C., Thompson, B. H., and King,
T. M., American fournal of Obstetrics and
Gynecology, 1973, 115, 1107.
3 Kajanoja, P., et al., fournal of Obstetrics and Gynaecology of the British Commonwealth Corson, S. L., and Bolognese, R. J., American fournal of Obstetrics and Gynecology, 1973 116, 893.

Prostaglandins, 1974, 5, 397.

6 Bradley-Watson, P. J., Beard, R. J., and Craft I. L., Fournal of Obstetrics and Gynaecology of the British Commonwealth, 1973, 80, 284.

Karim, S. M. M., and Sharma, S. D., Lancet, 1971, 2, 47.

Bygdeman, M., Toppozada, M., and Wiqvist, N. Acta Physiologica Scandinavica, 1971, 82, 415. Najak, Z., Hillier, K., and Karim, S. M. M. fournal of Obstetrics and Gynaecloogy of the British Commonwealth, 1970, 77, 701 .

Karim, S. M. M., Sharma, S. D., and Filshie, G. M., Fournal of Reproductive Medicine, 1972, 9, 383.

Bygdeman, M., et al., fournal of Reproductive Brenner, W. E. et al.

al., Prostaglandins, 1973, 3 Engei, T., et al., Fertility and Sterility, 1973, 24,

11 Choo, H. T., Karim, S. M. M., and Cheng, P., fournal of the Asian Federation of Obstetric and Gynaecology, 1973, 4, 71 . 5 Toppozada, M., et al., Prostaglandins, 1973, 4,

\section{Screening for Sickle-cell Disease}

SIR,-During a recent period of 12 months I screened all the newborn babies from Manchester and Stretford for haemoglobinopathy by haemoglobinelectrophoresis using the red cells from the capillary blood samples submitted for phenylketonuria testing. Of a total 7,691 samples, 29 showed the sickle-cell trait. The families of these babies were followed up and an additional 39 carriers were detected. No case of sicklecell disease was found. The only homozygote for haemoglobinopathy was a mother with $\mathrm{HbC}$ disease who had an uneventful delivery with a haemoglobin level of $9.0 \mathrm{~g} / 100$ $\mathrm{ml}$, picked up when we found the band for $\mathrm{HbC}$ in her baby.

In the light of this experience I have some reservations about random screening of British populations (leading article, 21 September, p. 701). Any screening programme will detect far more carriers than homozygotes, and there are real difficulties in dealing with the information thus gathered. How do we set about organizing the educational programme you recommend? Six mothers of babies with the trait were nunses. Only two knew about sicklecell disease. Their knowledge had oome from their nurse training, not from personal experience. Of all the parents I spoke to none knew anyone personally with sickle-cell disease or what were the symptoms of the disease. They all agreed that it was important that carriers should be told the results of tests; but it is very difficult to explain properly the significanoe of the carrier state without implying that it is an illness. Parents cannot understand the genetic implications of being carriers if they know nothing about the disease in question. If a programme of screening and education is to have a chance of success it must be run by black people and the impetus should come from the black community, ${ }^{1}$ but there are few individuals who could organize an educational programme in the black community here. In parts of the world where sickle-cell disease is common this must be less of a problem. Konotey-Ahulu has described 15 different terms for sickle-cell disease in Ghana, familiar even to illiterate grandparents. ${ }^{2}$ In the United States there have been problems with these programmes $^{34}$ and workers in Seattle have rceently described sickle-cll "non-disease." They have stopped screening because parents regarded their carrier children as having an illness. It was commonly stated "there must be something wrong because the doctor told us about it." It seems naive to assume that these experiences would not be repeated here.

Nor are our doctors better informed. Confusion between homozygous sickle-cell disease and heterozygous sickle-cell trait is commonplace. A similar problem is found in the United States. ${ }^{4}$ It is not surprising; few doctors have any personal experience of these cases. In my own investigation when the screening test for $\mathrm{HbS}$ was positive in a baby I spoke or wrote to the general practitioner concerned. The cases were not registered with a small nucleus of doctors in an immigrant area; the 29 babies were on the lists of 29 different doctors.

What is to be done about the carriers who need anaesthesia for dental extraction? The dangers of anaesthesia for major surgery in sickle-cell trait are well recognized, ${ }^{6}$ but is there any danger in the customary dental anaesthetic? No deaths from dental anaesthesia in sickle-cell trait have been reported and I do not know how much morbidity may have been produced by the quick gas in the dental chair; but throughout the world each year many sickle-cell carriers must have a dental anaesthetic without complications. Dentists are concerned about the need to screen for sickling.? In the absence of any advice to the contrary we err on the side of caution. Carriers are often anaesthetized with more than the customary care, with admission to hospital and consequent delay in treatment. This brings unnecessary expense and inconvenience for the patient. Is this really necessary? Is it another example of screening doing more harm than good?

The investigation was supported by a grant from the Childiren's Researah Fund. Further details will be published later.-I am, etc.,

D. I. K. Evans

Royal Manchester Children's Hospital,

Pendlebury,

near Manchester

1 Nalbandian, R. M., et al., fournal of the American Medical Association, 1971, 218. 1680 Konotey-Ahulu, F. I. D., in Sickle Cell Disease: Diagnosis, Management, Education and $R e$ search, p. 22, ed. H. Abramson, J. F. Bertles, Culliton, B. J., Science, 1972, 178, 283.

Beutler, E., et al. New Eng!and fournal of Medicine, 1971, 285 , 1485

Mampton, M. L.. et al.. American Fournal of Diceases of. Children, al $1974,128,58$.

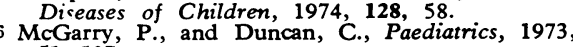
$51,507$.
Cotterill, E. C., British Dental fournal, 1974. 137, 153. 